\title{
Community Involvements to Handle the Pandemic Spread and the Impacts of COVID-19 in Indonesia
}

\author{
Berton Suar Pelita Panjaitan* \\ Fakultas Kedokteran \\ Universitas Jenderal Achmad Yani \\ Cimahi, Indonesia \\ *bertontria@gmail.com
}

\begin{abstract}
The COVID-19 pandemic has become worldwide problems, nevertheless it needs local countermeasures to cope with the spread and negative impacts of COVID-19. Indonesia consists of many local wisdoms that can be used to prevent the infections as well as to protect the communities from further reverse influences of COVID-19. Thus, a community involvement is a key to curb the pandemic and its impacts by using local wisdoms. This paper is to show several local wisdoms that empower the community members to be able to solve their problems with their own ways in Indonesia. The methods of collecting information are to revisit from the recent study as well as some publications. The community involvements in several locations in Indonesia have brought some insights on how the local wisdoms can be employed as a tool to prevent and to reduce the impacts of COVID-19. As a result of these observations in Aceh, Gorontalo, Central Java and Southeast Moluccas, in the absence of ideal procedures on Covid-19 pandemic it is worthy to applying their local wisdoms in order to prevent the pandemic and to lessen its negative impacts to the communities. A collective action of the local community members becomes a lesson learnt to encounter an adversity for a particular community.
\end{abstract}

Keywords-COVID-19, community involvement, local wisdoms

\section{INTRODUCTION}

In recent months, the intersection between effective public health response and community involvement in related to COVID-19 measures has come into greater focus in Indonesia. Since the emergence of COVID-19, community involvements have had imperative roles within human behaviours which decrease epidemic spread, transmission, and amplification. Community involvements matter due to community members can best recognize problems and solutions among them. As a place to various kinds of communities, Indonesia owns a lot of different local wisdoms in which are essential in the collective actions to COVID-19.

Although coping COVID-19 is still far from a success in Indonesia, community involvements have substantively coloured the COVID-19 escalation countermeasures. Every particular location has its own ways to participate to mitigate the pandemic through traditional channels and tenets. Central and local governments promote the community involvements as a better communication to the grassroots. As often found sophisticated, strange medical terms in handling this pandemic, a community involvement becomes a stronger empowerment and guidance to ensure all community members live without fear of losing their lives and livelihoods. Depoux et al. [1] mention that the pandemic of social media panic travels faster than the COVID-19 outbreak that potentially misleads rumours and conspiracy theories about the origin circulated the globe paired with fearmongering, racism and mass purchase of face masks.

Communities have rights and responsibilities to participate in the protection of their lives and to create harmonious living within their society through their local wisdoms. To realize these in terms of pandemics, it is imperative to carry out a number of actions by involving members of a community. This community involvement refers to a process of how people, households, and societies commerce accountability for their safety on COVID-19 so that they can improve their survival through the increase of their capacity. Therefore, community participation is an influential way of encouraging people to carry out their agreed objectives and the execution of meaningful programs [2].

Community involvement empowers local people to build various measures to prevent, prepare and be ready for worse situations. According to Letz [3] and Sutton and Tierney [4], community involvement can build strong awareness and educate local community members on life saving skills. It can also create and revitalize local early warning systems, cope resources, protect property, and initiate early recovery activities $[3,4]$. Furthermore, community involvement also supports community empowerment to influence their decisions affecting their lives. Lastly, it increases the effectiveness and efficiency on live saving actions from COVID-19 [2].

Community involvement in the context of COVID-19 should reflect three interconnected contexts [5]. Firstly, an emergency basis to seek a control of the problem should guarantee an adequate care for cases and economic safeguards for community members to survive during the pandemic. Secondly, strengthening the comprehensive public health services are urgently needed in place. Lastly, the social 
protection is changed to fulfil the community needs [5]. However, such information are hardly found in Indonesia since the pandemic is relatively new to the country as well as no existing surveys showed the important information. Meanwhile, there are no easy answers to these issues, any measures adapted would not be free from difficulties [6]. Thus, a community involvement guarantees two-way communication, and it would provide a sense of responsibility during this period. Community members should have a sense of ownership and participation, that they are playing a part in mitigating the outbreak of this deadly pandemic.

\section{METHODS}

This paper aims to provide some community involvements that have been implemented in Indonesia. To obtain this aim, a focus group discussion (FGD) with community and public leaders was applied to understand the questions, rumours, suggestions and concerns they are hearing about the new coronavirus. This method allows the researchers to collect qualitative data that gathers community individuals together to discuss a specific topic. As demonstrated by Akyıldız [7], the research questions were open-ended to stimulate the discussions with the participants to understand their perceptions, beliefs, fears, questions and leaderships in relation to the new coronavirus outbreak.

Due to the COVID-19 pandemic, the virtual interviews were applied to a number of 6-8 participants. Those participants were mainly the public leaders at the provincial level from the task force on COVID-19, Disaster Management Agency (BPDB), Health Service Agency, Public Information and Communication, public university and public hospital. With a confidentiality, the interviews were recorded, analysed and interpreted for the maximum results.

\section{RESULTS AND DISCUSSION}

As seen in Aceh, one of provinces in Indonesia, the sharia system is implemented in each administration levels of the government. Strong Islamic influences are easily found at the provincial government up to the smallest units of government (gampong=village). Aceh can produce special local regulations (Qanun) that regulate the administration of the local governments as well as the community day-to-day activities. At gampong level, a leader is named keuchik that executes the above tasks. A keuchik is a representative of the government as a leader, development communicator, Islamic role model and public servant [8]. In the early stage of COVID-19 pandemic in Aceh, keuchik has played its roles in handling the community. Through Qanun No. 5 of 2003 on Gampong and Provincial Government of Aceh, keuchik has conducted several steps to prevent COVID-19 among the villagers. To achieve that aim, 4,181 gampong had established the COVID-19 task forces where keuckik is the primary persons in charge. The keuchik had an important role to fetch the homecoming travellers to celebrate the 2020 Eid at the check points. The keuchik obligated them to self-isolation with gampong's responsibility [9]. As seen in the above finding, Buonsenso et al. [10] consider traditional concepts link religions with disease, since these concepts affect the responses of some categories of believers when in time of health crisis.

As WHO reminds that health protocols on COVID-19 prevention are uneasy to be caught up of most communities. Generally, Indonesians, in particular for those who live in rural, are very closed to each other. When "social distancing" is introduced to the public, a lot of confusions from the communities. Similarly, this program was not easily implemented in Gorontalo Province, in Sulawesi. Culturally, the people in Gorontalo practice ngala' $a$ (kinship) as a personal social and communal social interactions. As personal social interactions, ngala' $a$ is often used to show a close relationship such as teteyapuwa (caress), tata'apa (gentle pat) etc. [11]. Meanwhile, communal social interactions can be found in the shapes of depita (escorting foods one to another), huyula (working together), bilohe (seeing one another). These ngala' $a$ practices seemed not to support the social distancing protocol. However, depita can be used to care the infected people from COVID-19 by sharing and escorting foods for those who are in self-isolation. In line to using ngala' $a$ principal to cope with the impacts of COVID-19 to the infected, beleuto was also used during the rarity of medical masks. Beleuto is a kind of sarong that can be used by the females to cover their face [11]. At old times this traditional gown was often used to cover the body and face of a female. Since the COVID-19 pandemic, the provincial government of Gorontalo has encouraged the female public servants to use beleuto to office every Friday [12] in order to prevent them from COVID-19 infection. As demonstrated in Gorontalo, the involvement of women in preventing the pandemic is important, since they increase the gender roles and care responsibilities assigned to women and reduce violence among women [13].

From Central Java Province, we also find a jogo tonggo movement. Jogo tonggo is a concept to accelerate communitybased disaster (pageblug) management. In this regard, jogo tonggo puts pandemic COVID-19 as the target. Literally, jogo tonggo means a one's action to care one another in the neighbourhood. As a concept, a neighbourhood leader involves each community member to directly, of course with the health protocols for COVID-19, look after the impacted people from COVID-19. The people who are doing self-isolation for example, do not need to worry about their foods or the foods of their livestock because their health neighbours are actively involved in providing them [9]. As a movement, jogo tonggo is believed to be able to increase the knowledge of the public on the pandemic and its impacts. The governor of Central Java launched the Jogo Tonggo Program with an Instruction No.1 of 2020 on Community Empowerment of the Escalation COVID19 Management at Neighbourhood level. The aim of this program is together to handle COVID-19 prevention and impacts through working together movement and community empowerment with systematic, structured and comprehensive actions [14]. Through this program, [9] note the increase of the provision of non-medical masks and of people's usage of the masks outside of their homes. Moreover, jogo tonggo has reported those who are affected by the pandemic at the 
grassroot level so that they can access to the one of social safety net initiatives such as Hope Family Program, Food Card Program, Pre-employment Card Program, Power Tariff Reduction. Thus, jogo tonggo is one of actions is to be addressed during the pandemic due to it could provide many positive impacts to lessen the infections [5].

Similar actions we can see in Southeast Moluccas to cope with the impacts of COVID-19 pandemic. To anticipate that the people lack foods in the near future, the regent form this district along with TNI/Police Department and some certain community members have planted the local staples such as corns and tubers on the community gardens, known as ve'e kes yang. Ve'e kes yang (supply planting) is the implementation of lifestyle of Kei people with a motto "it foing fo kut it fo banglu watu" which is "we become one to face any challenges". The crops from ve'e kes yang have been shared for those who are in need at their ohoi (village) [15]. This practice shows that although the COVID-19 pandemic occurs, the social protection and survival are the important elements to be maintained by the community members [5].

\section{CONCLUSION}

Some local wisdoms from several local communities in Indonesia have been identified in giving benefits in order to reduce the gabs of understanding the protocols and the economic contraries due to the COVID-19 pandemic. In Aceh keuchik as a community, village, religion leader plays its roles for the coming people to self-isolate during the Eid celebration. In Gorontalo, understanding "social distancing" as one of health protocols on COVID-19 is difficult; but the local tenet of depita is used to care the infected people from COVID-19 by sharing and escorting foods for those who are in selfisolation. Also, beleuto is also used by the females to cover their face from COVID-19 in the absence of medical masks. Meanwhile, jogo tonggo from Central Java has increased the awareness and knowledge on COVID-19 and its impacts that allows neighbours to show their care within the neighbourhood. Lastly, ve'e kes yang tenet from Moluccas provides foods for those who are impacted by COVID-19. These community involvements have played their roles in the social protection and empowerment of the community members during the pandemic in some areas in Indonesia. As collective actions in counter the COVID-19 pandemic, local wisdoms have proved their essential benefits in the absence of an adequate health system when a pandemic occurs.

\section{ACKNOWLEDGMENTS}

The author wish to thank Dean of Medicine Department at the University of Jenderal Achmad Yani (Indonesia) with all team members that allows me to present this paper.

\section{REFERENCES}

[1] A. Depoux, S. Martin, E. Karafillakis, R. Preet, A. Wilder-Smith, and H. Larson, "The pandemic of social media panic travels faster than the COVID-19 outbreak," Journal of Travel Medicine, vol. 27(3), pp. 1-2, 2020

[2] G.M. Mathbor, Effective community participation in coastal development. Chicago, Il: Lyceum, 2008.

[3] H. Letz, Community-based preparedness and response to multi-hazard early warning. Geneva, Switzerland. [Online] available: http://www.medbox.org/early-warning/communitybased-preparednessand-response-to-multi-hazard-early-warning/toolboxes/preview? 2006.

[4] J. Sutton and K. Tierney, Disaster preparedness: Concepts, guidance, and research. Paper presented at the Disaster Preparedness Conference, California, 2006.2 anline] www.fritzinstitute.org/pdfs/whitepaper/disasterpreparednessconcepts.pdf,

[5] J.P.B. Junior and M.B. Morais, Community Participation in the Fight against COVID-19: Between Utilitarianism and Social Justice, Cadernos de Saúde Pública Report in Public Health, pp 1-9, 2020.

[6] E. Nelson, Coronavirus in Nigeria: A case for community engagement, 2020. [Online] available: https://www.thinkglobalhealth.org/article/coronavirus-nigeria-casecommunity-engagement..

[7] S. Akyıldız, "College students' views on the pandemic distance education: A focus group discussion," International Journal of Technology in Education and Science (IJTES), vol. 4, no. 4, pp. 322 334., 2020.

[8] H. Halimah, "Fungsi Keuchik dalam Pelayanan Publik di Kec. Glumpang Baro, Kab. Pidie,” Jurnal Warta, vol. 61 pp. 69-90, 2019.

[9] F. Lestari and R.D. Astuti, Pengalaman adalah Guru Terbaik: Sigap Melawan COVID-19 di Aceh eds Fatma Lestari et al Pengalaman Indonesia dalam Menghadapi Wabah COVID-19 di 17 Provinsi dan Pembelajaran dari Mancanegara. Jakarta: BNPB-Universitas Indonesia pp.1-22, 2020

[10] D. Buonsenso, W. Malorni, G.L. Sisti, and U. Moscato, COVID-19 and Religion: Risks and Opportunities. Preprints, 2020120173, 2020

[11] R. Modjo, Huyula and Beteuto, Pembelajaran dari Pandemi, eds Fatma Lestari et al Pengalaman Indonesia dalam Menghadapi Wabah COVID19 di 17 Provinsi dan Pembelajaran dari Mancanegara, Jakarta: BNPBUniversitas Indonesia pp 69-86, 2020.

[12] A. Ibrahim, Tuah Busana Kuno Gorontalo Beleuto Menangkal COVID19, liputan6.com, 2021. [Online] available: https://www.liputan6.com/regional/read/4342548/tuah-busana-kunogorontalo-beleuto-menangkal-covid-19

[13] Organization of American States COVID-19 in women's lives: Reasons to recognize the differential impacts, 2020. [Online] available: https://www.oas.org/es/cim/docs/ArgumentarioCOVID19-EN.pdf

[14] B. Aryo, Strategis "Jogo Tonggo" Jawa tengah Melawan Covid-19 Pembelajaran dari Pandemi, eds Fatma Lestari et al Pengalaman Indonesia dalam Menghadapi Wabah COVID-19 di 17 Provinsi dan Pembelajaran dari Mancanegara, Jakarta: BNPB-Universitas Indonesia, pp 99-129, 2020.

[15] R. Fitriati, F.J. Kayadoe, F.P Herin, Potong Pele COVID-19 Di Bumi Raja-Raja, eds Fatma Lestari et al Pengalaman Indonesia dalam Menghadapi Wabah COVID-19 di 17 Provinsi dan Pembelajaran dari Mancanegara, Jakarta: BNPB-Universitas Indonesia pp. 241-281, 2020. 